UDC 581.143.01.07

(C) 2016

Musiyenko M., Academician of the NAAS, Doctor of Biological Sciences

Storozhenko V., Batsmanova L., Serga O., Candidates of Biological Sciences

Grudina N., Makarenko V., Kovalenko M.,

Kyiv National Taras Shevchenko University

Artiushenko A.

Odessa State Agrarian University

\title{
SCREENING OF CULTIVARS OF WINTER WHEAT FOR SEARCHING GENOTYPES WITH THE HEIGHTENED ADAPTIVE POTENTIAL
}

The purpose. To screen new cultivars of wheat for selection of genotypes with the heightened adaptive potential in conditions of Steppe of Ukraine. Methods. Field, laboratory, mathematical-and-statistical. Results. The optimal for growing in conditions of Steppe of Ukraine and perspective for the further selection new cultivars of winter wheat are offered. Conclusions. Screening of new cultivars of wheat (Shpalivka, Taira, Shestyzerna, Staleva, Zolozerna, Ozerna, Tala, Shylovka, and Mahistral) has allowed selecting genotypes with the heightened adaptive potential in conditions of Steppe of Ukraine. Cultivars Shpalivka, Shestyzerna and Staleva are the most perspective for introduction and further selection.

Key words: wheat winter-annual, selection, screening.

Important component of big crops of winter wheat is successful selection of new cultivars which capable to use effectively the potential of fertility of soils, predecessors, crops terms and to sustain the negative impact of complex of stress factors which arise in agrocenosis. Influence of hostilities can be either short-term or prolonged and can have an effect during both several hours (fluctuation of temperatures and humidity) and several months (deficit of mineral nutrition). Therefore, the genetic potential of the majority of cultures is realized only for $20 \%$, as a rule [4].

The progressing climate aridization climate is the main hostility which determined first priority of studying of its role in the solution of practical approaches in productivity regulation of main agricultures in different climatic zones of the world [11, 13, 15, 16].

Drought happen even more often in all soil and climatic zones of Ukraine.

In recent years in our country observed record high temperatures of the average daily air temperature during spring and summer vegetation of plants. In 2013 temperature was above normal by $0,8^{\circ} \mathrm{C}$ from heading stage to flowering stage and by $1,5^{\circ} \mathrm{C}$ from milk stage (MR) to milky-wax ripeness stage (MVS). In general during period from flowering stage to milky-wax ripeness stage distinction on average daily temperature was 1,2 oC towards increase in comparison with average values for last years. In 2014 the above-mentioned tendency was become 
sharp. Particularly the average air temperature was higher than norm on 5,10C (flowering stage - milky-wax ripeness stage).

Therefore the great attention in selection work is paid to necessity of complex association of high level of stability of crops with high adaptive properties of new high yielder cultivars now.

Adaptation potential predetermines ecological tolerance and resistance of plants against unfavorable conditions of environment which provides guarantees of stability in implementation of genetically determined productivity potential. So, for effective maintaining of agricultural industry it is important to take into account not only genetic potential of plant productivity, but their resistance and capability to adapt for certain unfavorable conditions $[1,6,7]$.

The aim of investigation was screening of new cultivars of winter wheat for search of genotypes with the increased adaptation potential.

\section{Materials and methods}

New winter wheat cultivars were chosen as objects for investigation (Shpalivka, Tayra, Shestizerna, Staleva, Zolotozerna, Ozerna, Tala, Shilovka, Magistral), which were selected of farm "Bor" in Odessa region (originator of cultivars - Artyushenko P.M.).

Research was conducted in the conditions of field experiment on fields $\left(1 \mathrm{~m}^{2}\right.$ for each cultivar) in conditions of steppe zone of Ukraine (Dachnoye, Bilyayevsiy district, Farm "Bor", Odessa region). Agrotechnology of cultivation is standard. Samples of plant material selected in stem elongation and and flowering stages. The first developed leaf (stem elongation stage) and flag leaf (flowering stage) were used for analyses. Selection of plant material for analyses was carried out in identical stages.

Quantitative determination of chlorophyll content and total carotenoid content carried out by method [17], malonic diahdehide by method [2], proline by method [12].

Statistical treatment of results of investigation was carried out with help of computer program "Microsoft Excel" by Dospekhov [3].

\section{Results and discussion}

The contents and ratio of photosynthetic pigments are integral indicators which characterize state of photosynthetic apparatus and are the integral component of agromonitoring. Under edaphic-climatic conditions, identical to all studied cultivars, at the beginning of stem elongation stage the greatest values of the maintenance of chlorophyll has been established in leaves of winter wheat of Shpalivka and Staleva cultivars, the smallest was in leaves of Tayra and Shestizerna cultivars. At the end of this phase the biggest chlorophyll content was in leaves of Shestizerna and Tayra cultivars, and the smallest was in leaves of Staleva and Ozerna. 
In flowering stage the content of photosynthetic pigments was the highest in leaves of Ozerna and Staleva cultivars, and the lowest was in leaves of Magistral and Shilovka cultivars (tab. 1). Fluctuations of chlorophyll content in leaves during ontogenesis of plants can be appearance of ontogenetic changes and reactions of individual cultivars to weather conditions.

At the same time, the whole content of carotenoids in leaves of plants of wheat of all studied cultivars decreased in period from the beginning to the end of stem elongation stage. In the next flowering stage the content of carotinoids in leaves of plants of wheat of all cultivars increased a little. The ratio chlorophyll/carotinoids in stem elongation stage varied between 5,79-6,73, and in the end of this stage between 7,27-8,99. It was beetwen 4,44-5,89 in flowering stage (tab. 1). It is necessary to pay attention that it was the highest for Shpalivka and Staleva cultivars at the beginning stem elongation stage. At the end of this stage it was highest in leaves of Zolotozerna and Staleva cultivars. And in flowering stage it was highest in leaves of Shpalivka and Shestizerna cultivars, that characterizes great ability of plants of above-mentioned cultivars to absorb of photosynthetic active radiation.

At the same time, high values of this ratio for individual cultivars at the expense of the low carotenoid content, in our opinion, show their more balanced light-absorption, and smaller level of singlet oxygen generation under stress conditions [14] that is positive appearance of adaptation process.

The content of malonic dialdehide is one more classical index which characterizes oxidation-reduction status of plant organism. This is parameter which characterizes the level of lipid peroxidation. In our opinion, under identical conditions of cultivation for different cultivar this parameter together with others has to characterize their general physiological state. On the basis of it is possible to estimate of adaptive posibilities of individual cultivars under different conditions of cultivation.

Inverse relationship between the general content of chlorophyll and MDA in leaves in flowering stage is also revealed. So, under identical conditions of cultivation lipid peroxidation was the lowest in leaves of plant varieties of winter wheat with the high maintenance of chlorophyll. In our opinion, the ratio between these indicators characterizes potential abilities of many cultivars to detoxification of reactive oxygen species and ability to regulation of pro-antioxidant balance in photosynthetic apparatus (fig. 1).

Proline and other amino acids carry out osmoregulation function in leaves. High contents of free proline are biochemical index, the indicator of reaction of plants to action of stress factors. Potential distinction between the content of proline for cultivars can characterize adaptation opportunities of each cultivar under stress conditions. In our opinion, the high content of proline in leaves of investigated cultivars characterizes their big sensitivity to changes of humidity conditions, that has also been shown in works of other authors $[5,10]$. The content of free proline was the highest in leaves of Tayra, Staleva and Ozerna cultivars, and the lowest in leaves of Shpalivka and Shestizerna cultivars (fig. 2). 
The content of proline in leaves is very variable indicator. It's content can significantly change during plant development and interpretation of the received results on the basis of its contents requires take into account of many climatic and soil factors [5].

Important characteristics of physiological condition of plants are parameters of water relationships and morphometric indexes. The last most often correlate with parameters of biological effeciency, and water deficit is one of the most important limiting factors of big crops receiving.

Number of stomas on leaves and ratio of their quantity on the adaxial/abaxial side of leaf are important parameters of water relationships. The most large number of stomas on the adaxial side of leaf (per mm2) of winter wheat plants was in leaves of Tayra and Shestizerna cultivars (tab. 2) and on the abaxial size it was in leaves of Ozerna and Zolotozerna cultivars. At the same time, the specific quantity of stomas per flag leaf was another. Their most large number on the adaxial party of leaf was observed for Shilovka and Ozerna cultivars, and on the abaxial sites for Ozerna and Shilovka cultivars (tab. 2).

It is known that some works described the correlation between quantity of stomas on the abaxial/adaxial side of leaf and grain productivity of winter wheat [9].

High water-retaining capacity of leaves in tillering stage characterized of Shestizerna and Tayra cultivars and at the end of stem elongation stage Shestizerna cultivar has taken the 2nd place and Shilovka has taken first place. However in flowering stage the greatest water-retaining capacity in leaves had Magistral and Zolotozerna cultivars (tab. 3).

Such morphometric parameters as the stalk height, length of under-earing merithallus and ears as usual have no direct correlation communication with biological effeciency of plants. However this parameters are considered in fenotayping [8]. Plants of Magistal and Shpalivka cultivars had the greatest height of stalk, and Magistral and Shestizerna cultivars had the greatest length of underearing merithallus. Plants of Magistral and Shpalivka cultivars had the greatest length of ears. And number of cones in ears was the greatest in Magistal and Shpalivka cultivars (tab. 4).

Proceeding from the provided physiological and biochemical characteristics of studied cultivars of winter wheat in our opinion Shpalivka and Staleva cultivars have the highest adaptation potential in conditions of the Steppe of Ukraine and are the most valuable to further using in selection work.

\section{Conclusions}

Screening of new cultivars of wheat (Shpalivka, Tayra, Shestizerna, Staleva, Zolotozerna, Ozerna, Tala, Shilovka, Magistral) has allowed to allocate genotypes with increased adaptation potential in conditions of Steppe of Ukraine. Shpalivka, Shestizerna and Staleva cultivars are the most perspective for division into districts and further selection. 


\section{Bibliography}

1. Avramenko S. Dovedeno, shcho potencial urozhajnosti, jakij zakladact'sja na pochatkovyh etapah vegetaciyi ozimih zernovih, zalezhit' vid sistemi udobrennya / S. Avramenko, K. Man'ko, O. Usov, O. Kurilov, O. Bobrov // The $\begin{array}{llllll}\text { Ukrainian } & \text { Farmer. } & - & 2015 . & - & \text { № }\end{array}$ http://www.agrotimes.net/journals/article/potencial-urozhajnosti-ozimih.

2. Andreeva L.I. Modifikacija metoda opredelenija perekisej lipidov $\mathrm{v}$ teste $\mathrm{s}$ tiobarbiturovoj kislotoj / L.I. Andreeva, L.A. Kozhemjakin, A.A. Kishkun // Lab.delo. - 1988. - №11. - S.41-43.

3. Dospehov B.A. Metodika polevogo opyta / B.A. Dospehov - M.: Agropromizdat, 1985. - $351 \mathrm{~s}$.

4. Zubec' M.V. Nevidkladni zavdannja vchenih-selekcioneriv/ M.V. Zubec' // Visnik agrarnoï nauki. - 2000. - №12. - S. 5-9.

5. Major P.S. Vza€mozv'jazok mizh vmistom vil'nogo prolinu, rozchinnyh cukriv ta obvodnenistju tkanin u roslinah ozimoyi pshenyci protjagom osinn'o-zymovogo periodu / P.S. Major // Fiziologija i biohimija kul't. rastenij. - 2010. - T.42. № 4 - S. 298-305.

6. Morgun V.V. Fiziologicheskie osnovy formirovanija vysokoj produktivnosti zernovyh zlakov / V.V. Morgun, V.V. Shvartau,

D.A.

Kirizij //Fiziologija i biohimija kul't. rastenij. - 2010.- T.42, № 5. - S. 371-392.

7. Morgun V.V. Ekofiziologicheskie i geneticheskie aspekty adaptacii kul'turnyh rastenij k global'nym izmenenijam klimata / V.V. Morgun, D.A. Kirizij, T.M. Shadchina // Fiziologija i biohimija kul't. rastenij. 2010. - T.42, №1. - S. 3-22.

8. Musienko M.M. Morfologichnyj fenotajping sortiv pshenyci ozimoyi dlya vidboru genotypiv z pidvyishchenym adaptyvnym potencialom / M.M. Musienko, L. M. Batsmanova, N.S. Grudina, A.P. Artjushenko, V.O. Storozhenko // Visnik agrarnoyi nauky. - 2016. - № 3. - S. 35-

38.

9. Arminian A., Houshmand S, Knox R.E., Shiran B. Stomatal characteristics, heritability and their relation to grain yield in a double

haploid bred wheat population. In: Appels, R., Eastwood, R., Lagudah, E., Langridge, P., Mackay, M., McIntyre, L. and Sharp, P. (eds.). Proc. 11th Int. Wheat Gen. Symp., 24 - 29 August 2008, Brisbane, Australia.

2: 638-640.

10.Aspinall D. Proline Accumulation in the Grains, Floral Organs and Flag

Leaves of Wheat and Barley in Response to Variations in Water and Nitrogen Supply / D. Aspinall, K. V. M. Parameswaran, R.D. Graham // Irrig. Sci. - 1983. 4. - P. 157-166.

11.Barnabas B. The effect of drought and heat stress on reproductive processes in cereals / B. Barnabas, K. Jager, A. Feher // Plant, Cell Environment. - 2008. V.31. - P. 11-38. 
12.Bates L.S., Waldren R.P. and Teare I.D. Rapid determination of free proline for water-stress studies / L.S. Bates, R.P. Waldren and I.D. Teare // Plant and Soil. - 1973. - V. 39. - P. 205-207.

13.Farooq M. Plant drought stress: effects, mechanisms and management / $M$. Farooq, A. Wahid, N. Kobayashi , D. Fujita, S.M.A. Barsa // Sustainable Agriculture. - 2009. - P. 153-188.

14.Fanny R. Chemical Quenching of Singlet Oxygen by Carotenoids in Plants/ R.Fanny, S.Birtic, S.Cuine, C. Triantaphylide`s, J-L. Ravanat, M. Havaux // Plant Physiol. - 2012. - V. 158. - P. 1267-1278.

15.Hedhly A. Global warming and sexual plant reproduction / A. Hedhly, J.I. Hormaza , M. Herrero // Trends in Plant Science. - 2009. - V. 14, № 1. - P. 30-36.

16.Savchenko I. V., A.I. Pryanishnikov, A. I. Shabaev Scientific coverage of stable agricultural production under conditions of growing climate aridization//Russian Agricultural Sciences. - 2015. - V. 41, № 1. - P. $18-20$.

17.Wellburn A.R. The spectral determination of chlorophylls a and b, as well as total carotenoids, using various solvents with spectrophotometers of different resolution/ A.R. Wellburn // J. Plant Physiol. - 1994. - 144, N 3. - P. 307-313. 


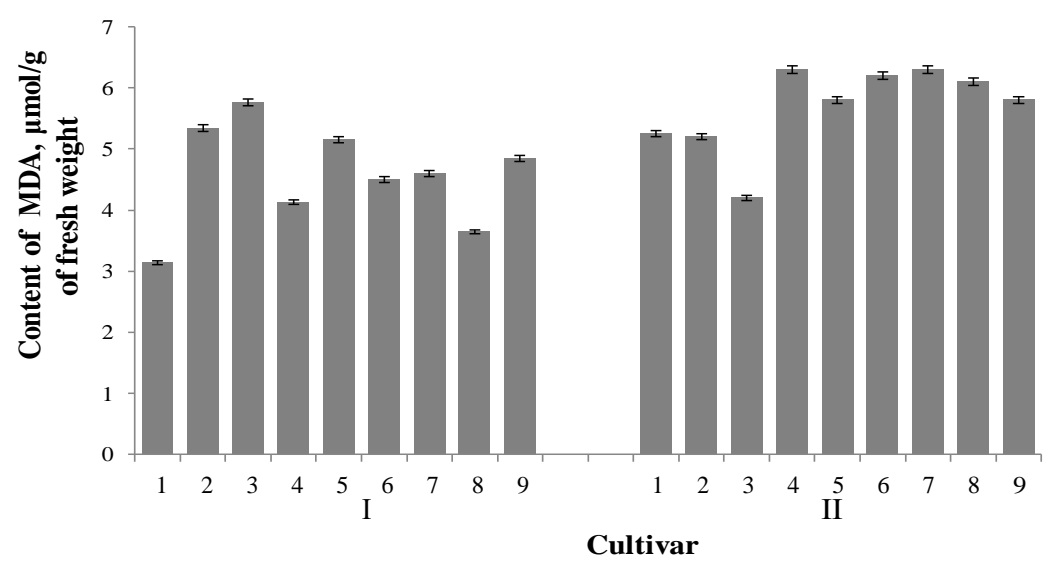

Fig. 1. Content of MDA in leaves of wheat plants on start (I) and end (II)of stem elongation stage : 1 - Shpalivka, 2 - Tayra, 3 - Shestizerna,

4 -Staleva, 5 - Zolotozerna, 6 - Ozerna, 7 - Tala, 8 - Shilovka, 9 - Magistral

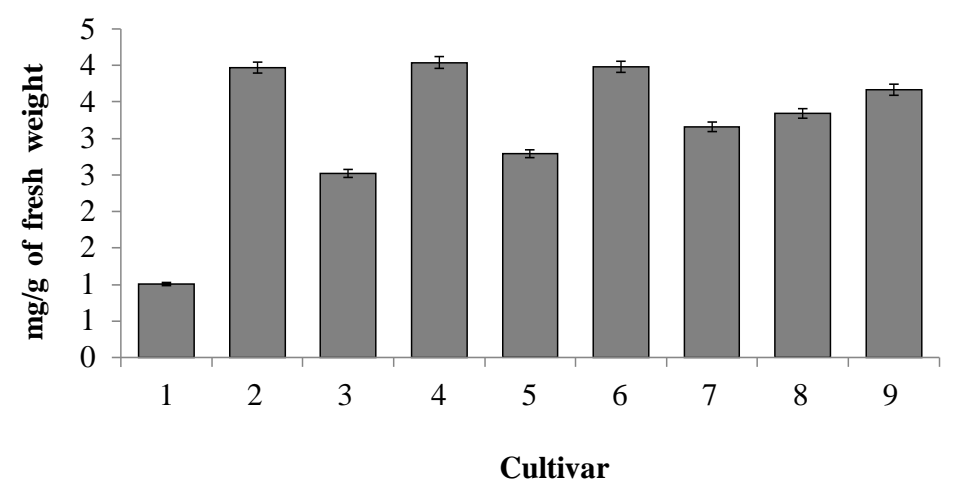

Fig. 2. Proline content in leaves of winter wheat plants of cultivars: 1 Shpalivka, 2 - Tayra, 3 - Shestyzerna, 4 - Staleva, 5 - Zolotozerna, 6 - Ozerna, 7 - Tala, 8 - Shilovka, 9 - Magistral 
Table 1. Content of photosynthetic pigments in leaves of winter wheat plants of steppe ecotype of Odessa selection

\begin{tabular}{|c|c|c|c|c|c|c|c|c|c|}
\hline \multirow[b]{2}{*}{ Cultivar } & \multicolumn{3}{|c|}{ Stem elongation stage (start) } & \multicolumn{3}{|c|}{ Stem elongation stage (end) } & \multicolumn{3}{|c|}{ Flowering stage } \\
\hline & \begin{tabular}{|c|}
$\mathrm{C}(\mathrm{a}+\mathrm{b})$ \\
(mg/g dry \\
weight)
\end{tabular} & $\begin{array}{c}\text { Ccar } \\
\text { (mg/g dry } \\
\text { weight) }\end{array}$ & $\begin{array}{c}\mathrm{C}(\mathrm{a}+\mathrm{b}) / \\
\mathrm{Ccar}\end{array}$ & $\begin{array}{c}\mathrm{C}(\mathrm{a}+\mathrm{b}) \\
\text { (mg/g dry } \\
\text { weight) }\end{array}$ & \begin{tabular}{|c|} 
Ccar \\
(mg/g \\
dry \\
weight) \\
\end{tabular} & $\begin{array}{c}\mathrm{C}(\mathrm{a}+\mathrm{b}) / \\
\mathrm{Ccar}\end{array}$ & $\begin{array}{c}\mathrm{C}(\mathrm{a}+\mathrm{b}) \\
\text { (mg/g dry } \\
\text { weight) }\end{array}$ & $\begin{array}{c}\text { Ccar } \\
\text { (mg/g dry } \\
\text { weight) }\end{array}$ & $\begin{array}{c}\mathrm{C}(\mathrm{a}+\mathrm{b}) / \\
\mathrm{Ccar}\end{array}$ \\
\hline Shpalivka & $11,4 \pm 0,2$ & $1,8 \pm 0,0$ & $6,3 \pm 0,1$ & $9,4 \pm 0,0$ & $1,1 \pm 0,0$ & $8,4 \pm 0,3$ & $8,5 \pm 0,3$ & $1,4 \pm 0,0$ & $5,9 \pm 0,1$ \\
\hline Tayra & $8,0 \pm 0,1$ & $1,4 \pm 0,0$ & $5,6 \pm 0,0$ & $10,0 \pm 0,2$ & $1,1 \pm 0,0$ & $8,9 \pm 0,4$ & $7,3 \pm 0,0$ & $1,6 \pm 0,0$ & $4,7 \pm 0,0$ \\
\hline \begin{tabular}{|l|} 
Shestizerna \\
\end{tabular} & $8,8 \pm 0,0$ & $1,6 \pm 0,0$ & $5,5 \pm 0,0$ & $10,9 \pm 0,2$ & $1,4 \pm 0,0$ & $7,7 \pm 0,0$ & $9,2 \pm 0,2$ & $1,7 \pm 0,0$ & $5,5 \pm 0,0$ \\
\hline Staleva & $11,0 \pm 0,2$ & $1,9 \pm 0,0$ & $5,8 \pm 0,0$ & $9,3 \pm 0,2$ & $1,0 \pm 0,1$ & $9,0 \pm 0,2$ & $9,6 \pm 0,1$ & $1,9 \pm 0,0$ & $5,2 \pm 0,0$ \\
\hline Zolotozerna & $9,1 \pm 0,5$ & $1,7 \pm 0,1$ & $5,6 \pm 0,1$ & $9,6 \pm 0,1$ & $1,1 \pm 0,0$ & $9,1 \pm 0,3$ & $7,8 \pm 0,1$ & $1,4 \pm 0,0$ & $5,4 \pm 0,1$ \\
\hline Ozerna & $9,6 \pm 0,3$ & $1,7 \pm 0,1$ & $5,8 \pm 0,1$ & $9,4 \pm 0,1$ & $1,2 \pm 0,0$ & $7,9 \pm 0,0$ & $10,1 \pm 0,1$ & $2,0 \pm 0,0$ & $5,0 \pm 0,0$ \\
\hline Tala & $9,5 \pm 0,6$ & $1,6 \pm 0,1$ & $5,8 \pm 0,1$ & $9,7 \pm 0,2$ & $1,3 \pm 0,0$ & $7,3 \pm 0,1$ & $7,8 \pm 0,1$ & $1,8 \pm 0,0$ & $4,4 \pm 0,0$ \\
\hline Shilovka & $10,5 \pm 0,4$ & $1,6 \pm 0,1$ & $6,7 \pm 0,1$ & $9,4 \pm 0,3$ & $1,2 \pm 0,0$ & $7,7 \pm 0,1$ & $6,9 \pm 0,1$ & $1,5 \pm 0,0$ & $4,6 \pm 0,0$ \\
\hline Magistral & $9,7 \pm 0,0$ & $1,7 \pm 0,0$ & $5,8 \pm 0,0$ & $9,6 \pm 0,1$ & $1,2 \pm 0,1$ & $8,3 \pm 0,3$ & $6,6 \pm 0,0$ & $1,4 \pm 0,0$ & $4,7 \pm 0,0$ \\
\hline
\end{tabular}

Table 2. Xeromorphicity of leaves of winter wheat plants in flowering stage

\begin{tabular}{|l|l|l|l|l|}
\hline \multirow{3}{*}{ Cultivar } & \multicolumn{3}{|l|}{$\begin{array}{l}\text { Number of stomata per } \mathrm{mm}^{2}, \\
\text { pieces }\end{array}$} & \multicolumn{2}{l|}{$\begin{array}{l}\text { Number of stomata per flag } \\
\text { leaf, pieces } \mathrm{x}^{3}\end{array}$} \\
\cline { 2 - 5 } & $\begin{array}{l}\text { Adaxial side of } \\
\text { leaf }\end{array}$ & $\begin{array}{l}\text { Abaxial side } \\
\text { of leaf }\end{array}$ & $\begin{array}{l}\text { Adaxial side } \\
\text { of leaf }\end{array}$ & $\begin{array}{l}\text { Abaxial side } \\
\text { of leaf }\end{array}$ \\
\hline Shpalivka & $73 \pm 2,2$ & $58 \pm 0,6$ & $132 \pm 2,1$ & $105 \pm 2,1$ \\
\hline Tayra & $83 \pm 1,3$ & $55 \pm 0,4$ & $144 \pm 3,3$ & $96 \pm 1,9$ \\
\hline Shestizerna & $76 \pm 0,9$ & $58 \pm 0,6$ & $128 \pm 1,4$ & $97 \pm 1,3$ \\
\hline Staleva & $67 \pm 1,5$ & $59 \pm 0,8$ & $132 \pm 2,4$ & $116 \pm 2,0$ \\
\hline Zolotozerna & $75 \pm 1,3$ & $63 \pm 0,6$ & $140 \pm 1,3$ & $117 \pm 1,8$ \\
\hline Ozerna & $70 \pm 1,2$ & $68 \pm 0,9$ & $168 \pm 3,2$ & $163 \pm 2,5$ \\
\hline Tala & $74 \pm 1,7$ & $57 \pm 1,0$ & $151 \pm 2,4$ & $116 \pm 1,9$ \\
\hline Shilovka & $70 \pm 1,4$ & $56 \pm 1,1$ & $176 \pm 3,1$ & $141 \pm 2,3$ \\
\hline Magistral & $70 \pm 1,3$ & $60 \pm 0,9$ & $160 \pm 2,3$ & $137 \pm 2,0$ \\
\hline
\end{tabular}

Table 3. Water-retaining capacity of leaves of winter wheat plants

\begin{tabular}{|l|l|l|l|}
\hline Cultivar & \multicolumn{1}{|c|}{$\begin{array}{c}\text { Stem elongation stage } \\
\text { (start) }\end{array}$} & $\begin{array}{c}\text { Stem elongation stage } \\
\text { (end) }\end{array}$ & Flowering stage \\
\hline & Rel. inits & \multicolumn{2}{|l|}{} \\
\hline Shpalivka & $18 \pm 1$ & $32 \pm 2$ & $23 \pm 2$ \\
\hline Tayra & $20 \pm 1$ & $37 \pm 2$ & $28 \pm 1$ \\
\hline Shestizerna & $21 \pm 2$ & $40 \pm 3$ & $23 \pm 2$ \\
\hline Staleva & $19 \pm 1$ & $23 \pm 1$ & $33 \pm 3$ \\
\hline Zolotozerna & $17 \pm 1$ & $32 \pm 2$ & $38 \pm 3$ \\
\hline Ozerna & $19 \pm 1$ & $42 \pm 3$ & $21 \pm 2$ \\
\hline
\end{tabular}




\begin{tabular}{|l|l|l|l|}
\hline Tala & $14 \pm 1$ & $43 \pm 3$ & $34 \pm 3$ \\
\hline Shilovka & $16 \pm 2$ & $53 \pm 4$ & $26 \pm 2$ \\
\hline Magistral & $16 \pm 1$ & $28 \pm 3$ & $43 \pm 4$ \\
\hline
\end{tabular}

Table 4. Morphometric parametrs of winter wheat plants

\begin{tabular}{|l|l|l|l|l|}
\hline \multicolumn{1}{|c|}{ Cultivar } & $\begin{array}{l}\text { Stalk height, } \\
\text { cm }\end{array}$ & $\begin{array}{l}\text { Length of } \\
\text { under-earing } \\
\text { merithallus, cm }\end{array}$ & $\begin{array}{l}\text { Length of } \\
\text { ear, cm }\end{array}$ & $\begin{array}{l}\text { Number of } \\
\text { cones in } \\
\text { leaves, }\end{array}$ \\
\hline & \multicolumn{4}{|c|}{ CM } \\
\hline Shpalivka & $68,0 \pm 1,3$ & $31,1 \pm 0,7$ & $9,4 \pm 0,2$ & $19,0 \pm 0,3$ \\
\hline Tayra & $62,3 \pm 0,8$ & $26,0 \pm 0,6$ & $9,0 \pm 0,2$ & $18,0 \pm 0,4$ \\
\hline Shestizerna & $67,7 \pm 1,4$ & $31,4 \pm 1,0$ & $9,5 \pm 0,2$ & $18,5 \pm 0,4$ \\
\hline Staleva & $65,1 \pm 1,1$ & $29,3 \pm 0,5$ & $8,9 \pm 0,2$ & $18,0 \pm 0,2$ \\
\hline Zolotozerna & $60,7 \pm 0,8$ & $27,0 \pm 0,4$ & $9,1 \pm 0,2$ & $18,0 \pm 0,3$ \\
\hline Ozerna & $61,2 \pm 1,4$ & $28,5 \pm 0,5$ & $10,0 \pm 0,2$ & $17,0 \pm 0,3$ \\
\hline Tala & $65,0 \pm 1,4$ & $28,9 \pm 0,9$ & $9,2 \pm 0,3$ & $18,1 \pm 0,4$ \\
\hline Shilovka & $68,4 \pm 0,9$ & $31,3 \pm 1,0$ & $9,6 \pm 0,2$ & $18,0 \pm 0,4$ \\
\hline Magistral & $84,4 \pm 1,2$ & $33,6 \pm 1,1$ & $10,1 \pm 0,2$ & $19,0 \pm 0,5$ \\
\hline
\end{tabular}

